



\section{On the Nature and Control of the White Pine Blister Rust}
Copyright, 1920, by Fred Reinlein, 1751 Derby St., Portland, Ore.

Date of Final Printing, April 19, 1920

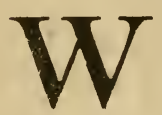

HAT is claimed by the Office of Forest Pathology, of the Bureau of Plant Industry, to be a correct analysis of the nature of a disease killing white pines is given under the above name in Farmers' Bulletin No. 742, written by Dr. Perley Spaulding. The disease is there claimed to be "caused by a parasitic fungus" (p. 1).

In my Circular No. 152 , pp. 26 to 32 , issued in 1918,1 showed that the disease that really kills the pines is bacterial in nature, and that what parasitic fungus occurs on the pines is merely the hibernating form of a fungus affecting currant and gooseberry bushes in summer, and I claimed that if the currants and gooseberries were eradicated, "the disease that is killing the pines is there as before" (p. 28).

I tried to get Dr. Spaulding to criticize the evidence I submitted, but in vain. I then made the same effort with several State Pathologists that had done research work in this line. Of these Pathologists, only Prof. F. C. Stewarl, of the New York State Experiment Station at Geneva, made a reply. Mr. Steward, with Mr. W. H. Rankin, had gotten out State Bulletin No. 374: "Does Cronartium rebicola over 


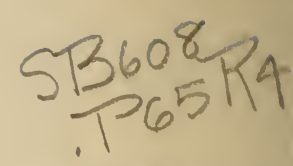

winter on the currant?" M. rSteward stated: "... I pre- D fer not to make any statement concerning the pine blister rust except to say that your theory as to the nature of the disease is entirely incorrect."

".since the white pines of the United States are estimated to be worth $\$ 423,000,000$ and those of Canada $\$ 200,000,000$ additional it is felt that no chances of a further spread of the blister rust can be taken" (Farm Bul. No. 1024, p. 25). Thus since the Bureau of Plant Industry professes to be wanting to serve the interests of the public, they ought to be eager to criticize the more complete evidence in support of my claims I am now going to submit.

The life circuit of the white pine blister rust fungus as understood and illustrated by Mr. Spaulding in Figure 4 of Farmers' Bulletin No. 742 is just what I claim it in my Circular No. 152 to be-the circuit of a fungus affecting currant leaves in summer and hibernating on diseased parts of pine in winter. No reference is made in Figure 4 and accompanying text to pycnidial drops and to pycnospores living in them, nor to their appearance before the spring form of the rust, the peridermium spores, appear on the swollen or already cankerous bark.

Unsupported theory enters through Dr. Spaulding claiming on page 11 that these pycnidial drops are merely indicators of the disease, meaning by the disease the rust fungus, but understanding by rust fungus in this case not merely the circuit formed by teliospores lodging upon pine in the fall and generating peridermium spores on pine in the spring and these

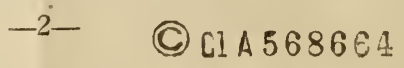


peridermium spores generating uredospores on currants, and these uredospores by late summer generating teliospores on currants as given in Figure 4, but also wanting it understood that the canker killing the pines is caused by these forms of rust; in other words Dr Spaulding wants it understood, that the swelling of the diseased parts and the formation of pycnidial drops is merely incidental to the life circuit on pine of a rust that in summer lives on currants.

On the other hand I not only put up the theory that these pycnidial drops serve a purpose, but also showed that they have nothing to do directly with the life circuit of the rust fungus, since they occur both "early in the spring ..... or they may occur apparently at almost any season in late summer and fall "(F. B. 742, p. 11). I showed that as the fungus disease is in summer admittedly absent from pines, the origin of pycnidial drops "with immense numbers of tiny sporebodies" (p. 11) occurring during summer and fall on pine cannot be ascribed to the rust fungus, I having originally specifically pointed out that there are then no teliospores present to produce them, since these only occur in the fall.

"What the function of these tiny spores "(pycnospores, living in the pycnidial drops)" may be nobody knows. . . . . They are simply indicators of the disease" (p. 11). Talk about theory. First, Dr. Spaulding says, nobody knows what they are, and then he claims to know what they are. Not only this, but he expressly claims they have their origin through the hibernating form (teliospores) of the rust fungus "The teliospores, falling upon bark of suitable age on a white 
pine, may in turn germinate, penetrate the bark and grow in the inner layers during the incubation period already mentioned" (p. 14). The incubation period lasts without outward sign from less than a year to 6 or more years (p. 11). "This infection of the pine bark must take place in the late summer of fall. If the parasite "(the teliospore)" finds condtiions very favorable, it may produce the sweetish drops of liquid with the pycnospores early the next spring and shortly after that it may produce the blisters containing the peridermium spores. .." (p. 14). This is on a par with saying that a potato planted for a crop can, for an indicator of a crop, first hatch a chicken--for I shall show that the pycnospores are microbes, which are considered to be of animal life-and then later, for a crop, produce a bunch of tubers.

As stated before the life circuit of the fungus admittedly does not require any pycnospores to complete it. Then how is Dr. Spaulding to prove his claim that teliospores produce the pycnidial drops, with the pycnospores they contain? Not only can he not prove his contention, but it can be shown that a teliospore falling upon previously diseased bark produces a blister of peridermium spores in the spring and nothing else. This, I have to admit, was not very clearly shown in my Circular No. 152. I merely there stated that as the pycnidial drops containing pycnospores occur besides in the spring also "apparently at almost any season in late summer and fall," it follows they cannot be caused by teliospores, as these are just then forming upon currant leaves and are blown 
to pines by the wind, requiring development within the bark before they can produce anything.

That the bark must be already diseased before a teliospore can sprout on it, is shown, in addition, by the fact that the teliospores produce the peridermium spores only in certain places, shown to be diseased by a swelling or a canker. whereas these teliospores are blown by the wind all over the tree, as would snowflakes for instance. Hence, if they could sprout on sound bark, peridermium spores would appear on all of the bark of suitable age in the spring. And having thus shown that teliospores sprout only on diseased bark, this means they cannot infect sound bark to start the disease that produces the diseased bark, which proves that we have to do with two distinct diseases, as claimed, one which we will call and which really is a bacterial disease-the disease that really kills the pines-and another, a rust fungus, living in summer on currant leaves and in winter on pine bark, diseased by a canker in various stages of dérelopment. The teliospore is credited with having started in some cases the disease as long as 6 or more years before it becomes outwardly visible through swelling of the bark and the appearance of pycnidial drops. But no proof whatever is given that a spore of a parasitic fungus ever could do such a thing. But then "The life history of this parasite is very complex" (p. 11), according to Dr. Spaulding, after giving in Figure 4 what he declares to be, and in reality is, the life circuit of the causal fungus of the white pine blister rust, a circuit of fungus as can be "paralleled by a great number of related fungi" (p. 11). I would appreciate 
having one or two of such most closely related fungi specifically mentioned.

The trouble affecting the pines can be explained therefore in a perfectly satisfactory manner only by assuming that the pycnospores are microbes similar to those contained in similar exudations occurring in pear blight and other cankerous disseases, that they are carried by insects, or possibly birds, or other agencies to bark of suitable age on other pines and by stinging or rasping or possibly merely smearing are thus given access to the tissues. It is hard to see how there can be much proof to show that the disease was present a specified time, such as 6 or more years, before swelling of the bark made it apparent. There appears to be no record that a fungus can cause such swelling, but there is ample record that $\mathrm{mi-}$ crobes can. This swelling, it is reasonable to assume, is due to congestion of diseased sap and the pycnidial drops are the natural result. The pycnospores therefore must be assumed to be a form of low animal organism working in the tissues. This is further indicated by an examination of Figure 4 and Plate I which show very little swelling left by the time the peridermium spores appear. Each peridermium spore cluster there shown is clearly the result of a successful infestation by one teliospore the fall before, each cluster developing independently of the other. An examination will show that these peridermium clusters cannot apparently utilize any great amount of sap; to all appearances they merely utilize as much sap in comparison with their size as do uredospores and teliospores, the summer and fall form of the rust, on currant leaves. 
The text accompanying Figure 4 claims in part:

The late summer stage ... infects neighboring white pine which may and may not include the pine which bore the blisters that started the outbreak the preceding spring." Now ".... No tree infected with this disease has ever been known to recover. .." (F. B. No. 1024, p. 23). Hence you here have an admission that a tree may not have been re-in. fested with teliospores the fall before and yet in any case remained diseased the following summer. This proves that destruction of all currants and gooseberries within range of infection does not stop the disease that kills, the pines.

It dos not follow from this that there is no connection between the presence of currants and gooseberries and the spread of the bacterial disease that kills the pines. There certainly does seem to exist a connection. The insect or other agent that carries most of the pycnidial fluid to other pines may be attracted by the blooms of currants and gooseberries and later by the fruit. Or the insect may be predaceous upon the currant aphis. Or it may be parasitic upon the currant worm. Removal of currants and gooseberries would then tend to keep the insect away. On th other hand once some pines produce pycnidial drops there is no reason to believe that since these pycnidial drops are attractive to insects on their own account mere removal of currants and gooseberries everywhere would prevent all future infection.

Since therefore we must look upon the removal of currants and gooseberries near white pine as a step likely to reduce the degree of infection, the question of how this is best 
accomplished is to be considered. "Various chemicals and sprays are being tested in the hope of finding a cheap and practical means of killing wild Ribes. The results obtained indicate that dip oil, fuel oil and possibly sodium arsenite an be used economically to destroy dense growths of Ribes where the cost of hand pulling is excessive" (1919 Report, Bureau of Plant Industry, p. 39).

Nothing cheaper or more practical for killing wild ribes will be found than a light, longhandled pick ax, one end pointed and the other with a one or two-inch transverse cutting edge. This allows of grubbing, cutting, yanking and pulling, all without any hand pulling, except possibly some torn off roots that might otherwise sucker.

Substantially this same coure holds good in the present campaign for the removal of barberry bushes, a plant thit is necessary as an alternate food plant in the spread of the black stem rust in latitudes where the summer form of rust cannot hibernate. "The number of localities in which wild bushes are found is immensely larger than was believed.... the seeds having been sown in large numbers in thickets and woodlands by wild birds. The difficulty of locating such bushes in rough and broken timberland, oftentimes amid. thickets and underbrush will be appreciated by any one who undertakes it..." (1919. Report, Bureau of Plant Industry, p. 33).

The difficulty of removing will be still more appreciated than that of locating if it is to be done by the official method recommended and shown on page 1 of Farmers' Bulletin 
No. 1985 as: "The proper way to remove barberry bushes. Dig deep enough to get all the roots." A bush about 4 feet high is there shown, on smooth ground and isolated, as being dug out with a spade. It is false to claim that you need all the roots. You do need all of the surface roots. The roots going down can be cut off below the root stock. An attempt to work a spade in a thicket on a 1 ? foot bush would result likely in cutting some top roots to pieces, causing suckers. In thickets, or with bushes growing among heavy clumps of grasses or among rocks, a pick ax with usual length of handle, one end pointed and the other cutting one or two inches transversely will first tear the surface roots off, they to be pulled out then whole by hand, and the taproots, which do not sucker, can then be cut or yanked off, making work very thorough and comparatively very easy in the most difficult situations.

This then removes one of the best food plants the wild birds have and means corresponding decrease in the abundance of the birds, or else a necessity on their parts to make up this loss on cultivated crops.

If a man is able to show nothing further than that the cankerous disease that kills the pines exists independently of the fungus rust affecting leaves of currants and gooseberries in summer and hibernating on diseased parts of pine, he has shown something of great value to the forest interests of the country especially in the infested territory and still more so in the territory infested by the gypsy moth. It means that the removal of currants and gooseberries, en- 
tirely, or within certain zones considered safe by the Bureau of Plant Industry, does not result in stopping all spread of the risease that kills the pines as claimed by the Bureau. It means that as long as a satisfactory way to reduce the numbers of carriers of pycnidial fluid yet present after the currants and gooseberries have been removed is not found, planting white pine is virtually certain to be money thrown away.

No satisfactory remedy is in sight or likely to come in sight, hence it is clear that the interests of all the country at large demand that the public be told the truth. The Department of Agriculture is created and gets each year a nice handful of shekels to promote agriculture in its broadest sense and not to humbug the people with their own good money, or at least with part of it. Moreover this matter is entirely independent of the many other issues relating to insect and fungus control on which the Department of Agriculture has during the past 22 years been too bashful to make any statements, a matter discussed in my Circulars No. 155 to $15 \%$.

"Moreover, within the area worst affected by the gipsymoth, the forests are being converted into white pine" (upon the advice, or at least with the knowledge, of the supposedly learned and honest men of the Bureau of Entomology, that want to shut their eyes so the fact, that the European pine shootmoth is now there to ruin what might escape the gipsymoth) "as rapidly as possible, because this species is far the most valuable one which is not seriously injured by this insect. More than this the white pine, in many sections at 
least, is much the most valuable tree now available for future forests. Its loss would be a real catastrophe, for no other tree can take its place" (F. B. No. 742, p. 6).

"Many of the so-called hard pines, having leaves in twos and threes, have been exposed to infestation in Europe but have never taken the disease. . ." But the planting of hard pines cannot unconditionally be recommended either, because of the presence of the European pine shoot moth, which by preference attacks the apical bud and causes crooked and stunted pines, for the control of which moth the Bureau has no feasible means of control. A proper system of control has been described by me as far back as 1915 in my Circular No. 145. A short description is given on pages 5,17 to 20 , and on page 22 of my Circular No. 155. It consists in pouring some semi-liquid clay before oviposition begins into the apical whorl of buds. The moths then oriposit on the lateral branches. This use of clay is feasible only on the smaller trees. To protect the trees at large a system of light trapping by using some such torch as shown on last page in conjunction with certain fittings and a steaming sweetened decoction of pine twigs was described by me in Circular No. 155. No official action was taken, this system of trapping having been evolved during the past 5 years. It has been pointed out to the Bureau of Entomology that such a trap would be of value in controlling the giysy moth in woodlands by trapping the males. The Bureau was all the more urged to test this matter out, as I wanted to get fair treatment before $I$ would describe a device I have in mind that will take care 
of insects that go to electric lights. For the present there is nothing better available in this case than a torch trap, same as to be used in the woods, to be mounted near such lights and to be used in connection with sweet smelling substances as described in Circular No. 155.

In addition I pointed out as a means of controlling the gipsy moth that the woodlands could be made to support large flocks of poultry, that poultry could pick there the largest part of their keep most of the year, and could secure young caterpillars of the gipsy moth through the habit of these caterpillars of letting themselves down to the ground sometimes, could secure and eat as many of the large caterpillars that crawl down the trunk towards morning to hide near the base as they can stand, could find and eat eggs on or near the ground and could find many of the females hiding on the ground or on the underbrush during the day. I showed that poultry could thus also keep down many other insects and could fatten largely on acorns in the fall, and that with these means of control available it is all wrong to advise the suppression of oak in favor of planted white pine.

Having shown that the disease, which kills white pine and which furnishes in bark thus diseased the means for completing the life cycle of a rust affecting currant leaves in summer, is caused by a low animal organism similar to that causing pear blight, what means are there for its control?

"... The disease may kill the largest tree. (F. B. No. 742, p. 6). "The blister rust first attacks the twigs of a pine tree and then gradually works into the larges 
branches and the trunk" (F. B. No. 1024, p. 23), “ . . a an old tree ... is likely to have everyone of its lateral branches as well as the top center shoot, attacked and finally killed" (F. B. No. 742, p. 6).

It is evident that the disease is spread by some agency such as an insect or a bird picking on the pycnidial drops and carrying the pycnospores to other pine. A tree grown for timber and subject to various diseases and insects throughout its life cannot stand much expense for treatment at anyone time. Hence the mosi. feasible means of control seems to consist in trying to destroy or keep away the carriers from the pycnidial drops. These drops, when the disease is well established, will be ustudly out of reach. It is not even likely that it would pay to give special attention to each tree where these drops are within reach once there is general infestation. However one such means for smaller trees I pointed out on page 31 of my Circular No. 152: “... the most feasible course consists in taking a little white pine-or other handy evergreen branch and slap this about the infested parts of the pines and do this while the pycnidial drops are present, especially in the spring. It would seem certain that this causes the pycnidial drops to dry up, thus killing the microbes they contain...." A further suggestion: Where the canker is - near the ground, soil might be ridged up to it. If too high, soil dug with a spade and thrown into the branches and sticking to the canker might help to dry up the pycnidial drops. With an evergreen branch these drops could be brushed off when occurring at considerable hight. I repeat I do not think 
it could be made to pay.

It must be borne in mind that pines thus affected by tha disease, because of their weakened condition, invite borers and that at present there is no practical official means of control for these. The official means adıcated is the removal of infested trees while dormant. Thus in one of two pine trees, located about 1 1-4 miles from the New York State Experiment Station and traced through infecting currants near by to be the source of rust infestation on currants at the station, Mr. Steward found borers.working. These borers could be trapped in large numbers by the use of a torch trap as previously referred to. In doing this the presence of other insects present-injurious, beneficial and neutral-must also be considered. The Bureau of Entomology never took this matter up, although shown the need in many ways for the past seven years in my Circulars No. 139 to $15 \%$. With a proper system of trapping carried on with a view to control insects amenable to trapping in general many trees can/be profitably saved that otherwise would succumb.

It might be that the cankerous disease in question is spread by borers and trapping them as fast as possible would then be the most feasible means. If, as is more likely, flies, wasps and bees spread it, there seem two ways open to give relief. First, provide, if possible, suitable food plants that furnish nectar to draw them away from the sweet-tasting pycnidial drops, and, second, if the first course is not possible because of absence of clear land near by, use repellants to drive them away. It should be possible in the majority of 
cases to use a barrel spray pump fastened on a pointed stoneboat for the application of some such deterrent spray as crude oil to the trunks of some of the big trees, just enough to render the grove uninviting to the carriers. Or the opposite course might be used: Scented poisoned sweets might be exposed to draw them away from the sweet-tasting drops. Of course it would have to be determined to whot extent thus beneficial insects like bees are destroyed. In that case the carriers might be fed on unpoisoned sweets in an effort to draw them away. Young trees might be protected by spraying some kind of rubbish such as straw, weeds, evergreen twigs with some repellant such as crude oil and distribute them over or among the trees.

As for the rust on currants "... spraying has not proved practical or successful in preventing infection or in killing the fungus after it attacks the currant and gooseberry leaves ..." (F. B. No. 1024, p. 24). I quote for a remedy from my Circular No. 152, p. 28): “ . . The fungus disease on currants can easiest be kept.down by an occasional slight licking of the underside of the leaves with a hot air blast torch, a suitable type of which is shown on last page. This was pointed out by me as far back as 1898 , but the Bureau of Plant Industry never made any tests to satisfy themselves." Such licking would cause the voracious larvae of the twobrooded imported currant worm to drop to the ground to be killed there by the heat at close range. The Bureau of Entomology advises the use of poison. This at best is successful only with small worms and does not go well together with 
ripening fruit. Sucking insects like scales and lice readily succumb to occasional swift lickings with a blast.

Another very serious danger now threatens the pines of the East. This is the European pine saw fly. It was first discovered in Connecticut in 1914 and is described in the Connecticut Experiment Station report for 1915. I quote: "This species is one of the most injurious saw flies on European conifers . . . it has a large number of host trees . . and . . . would do a great deal of damage ..." (p. 119). It has two broods in Connecticut. In the breeding cages all cocoons (of both broods) were made on twigs. "In Europe, raking up and destroying the leaves and other rubbish under the trees in fall is recommended to destroy the cocoons" (of the hibernating brood). If the cocoons of the second brood are on the ground, there is one means of control feasible-the use of poultry on a large scale. But if the hibernating cocoons are made on twigs no means of control is feasible since the use of arsenicals on timber treess to kill the larvae is out of question. One conceivable means of control would be the attraction of the adults to poisoned sweetened baits, always involving the risk of poisoning many beneficial insects. Also poultry might destroy such larvae as fall down or are blown down by wind, suspend themselves near the ground or crawl over the ground to other trees in case of shortage of food.

This pest may be present in many other places right now, similarly as was the case with the European pine shoot moth after it was discovered in 1914 when it was found within? months "in 20 localities in 9 states with very strong indica- 
tions of infestations in several widely distributed localities." As for the cankerous disease affecting the varieties of white pine the disease will either wipe them out or there will survive some trees entirely or partly immune, the seed from which will finally serve for new stock. In any case this is a bad time for the Department of Agriculture to advise the planting of white pine, the more so now that it has been shown that the disease exists independently of currants, and that there is no promise that palliative measures can be made to pay. It is therefore the plain duty of the Department of Agriculture in this matter to admit that I am right or show why I should be wrong, something they were wanted to do in regard to other issues pending for 22 years past.

What other tree might then be handy to fill the place of pine? In conifers larch would probably best do that. Its chief enemy is the larch sawfly. This insect has been at times very destructive because no official means of control was known. As far back as my Circular No. 149, p. 16. I pointed out, that since this fly is present as larva or pupa in a cocoon on the ground 10 months out of 12 , it could be easily controlled by the use of poultry. According to the U. S. HumBugologist this with all else I ever wrote in the matter of insect control is wrong.

Of deciduous trees the catalpa is one of the best for growing timber. The gipsy moth virtually cannot live on it. It is however attacked by the catalpa sphinx, which frequently causes complete defoliation. There is no practical official means of control, since the use of arsenical sprays for the 
larvae and "to spade up the ground thoroughl yand disintegrate it in the fall so as to destroy the pupae. .concentrated... in the immediate vicinity of the trunk" (F. B. No. 705, p. 9) advocated by the Bureau are out of question on a tree grown for timber. On page 8 of my circular No. 149, I pointed out that since the insect pupates in the rubbish under the trees, giving poultry the run of the woods, keeps the pest under control. But the U. S. Bum-Bugologist says I am wrong, thus not only withholding official endorsement of a good method, but actually fighting it contrary to the interests of the people.

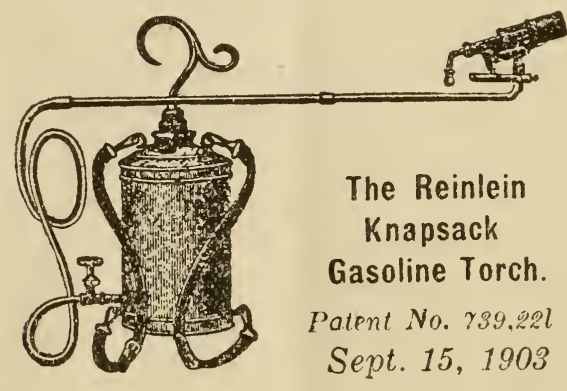



OF CONGRESS

00214902783 

